\title{
THE USE OF PROVERBS AND ANTI-PROVERBS IN TEACHING ENGLISH TO SECONDARY SCHOOL STUDENTS
}

\author{
Elena Gennadyevna Kotova $^{{ }^{*}}$, Alesya Vyatcheslavovna Leontyeva ${ }^{2}$, Elena Aleksandrovna \\ Lineva ${ }^{1}$, Mariia Victorovna Ovchinnikova ${ }^{1}$, Elena Borisovna Saveleva ${ }^{3}$, and Nataliya \\ Vladimirovna Akimova ${ }^{4}$ \\ ${ }^{1}$ English Philology and Translation Studies Department, State University of Humanities and \\ Technology \\ ${ }^{2}$ Foreign Philology Department, Institute of Humanities, Moscow City University \\ ${ }^{3}$ Romano-Germanic Philology Department, State University of Humanities and Technology \\ ${ }^{4}$ Linguodidactics Department, Moscow Region State University
}

\begin{abstract}
Language and culture co-study issues have a permanent tendency to be interpreted from the view point of socio-cultural competence. In this regard, a foreign language teacher faces the problem of creating pedagogical conditions for the effective development of linguistic and socio-cultural competencies of students in order to acquire the ability to use a foreign language in the process of intercultural communication. As one of the ways to solve this problem, the authors of the article suggest using authentic proverbial material in the process of teaching a foreign language. The authors believe that the national culture and modern language trends are most fully and vividly manifested in the paremiological units of the language, which include Proverbs and antiProverbs. Their use at different stages of learning a foreign language will become an additional source of background knowledge about the country of a target language and contribute to the evaluation of students' language and speaking skills. With the help of experimental and diagnostic training, the authors are trying to prove and justify the effectiveness of using authentic proverbial material in the process of teaching a foreign language to secondary school students of the 9th grade. The analysis of empirical data has shown that indicators of socio-cultural and linguistic competence development are the abilities of students to interpret adequately background information and use a set of language tools for intercultural communication. Participants of experimental diagnostic testing objectively improved the indicators of the level of training and demonstrated the abitity to use background knowledge fluently.
\end{abstract}

* Corresponding author: kotova070809@yandex.ru 


\section{Introduction}

Modern society is characterized by an accelerating pace of life, rapid political, socioeconomic transformations, globalization and multicultural world development. The main goal of teaching foreign languages in secondary schools is to develop students ' abilities to use a foreign language as a tool in the dialogue of civilizations and cultures of the modern world. Along with the development of students' foreign language communication skills (linguistic competence), the acquiring of socio-cultural competence and its components is important for learners as well. In the modern theory and practice of teaching foreign languages this issue is given great attention to. A high level of linguistic and socio-cultural competencies are necessary to perform a competitive interaction. The possibility of using proverbial material possessing special cultural and pragmatic potential in teaching a foreign language is very important for the process of socio-cultural competence development. The national and cultural identity of a native speaker is entirely revealed in paroemiological units. These units include Proverbs and anti-Proverbs (a modified form of traditional paremia). Revealing the background of national social experience, Proverbs and antiProverbs serve as containers of linguistic and cultural codes of the language. Their usage in teaching foreign languages turns out to be an additional source of background knowledge. It greatly contributes to mastering students' speaking kills as well.

The use of authentic proverbial material combined with cross-cultural studiesis an effective tool of linguistic and socio-cultural competences development at all stages of education in a secondary school.

The object of this research is the process of teaching a foreign language in a secondary school.

The subject of the research is the use of Proverbs and anti-Proverbs in the process of linguistic and socio-cultural competencies development of secondary school students.

The aim of this work is a detailed description of the theoretical basis for the use of paroemiological units (Proverbs and anti-Proverbs) in the process of teaching a foreign language to secondary school students and implementation of the developed set of exercises in educational activities for evaluation linguistic and sociocultural competences of learners.

\section{Overview of sources}

The problem of including cultural components in the process of teaching a foreign language is not a new one. The urgent necessity to study culture, traditions and customs of native speakers is generally recognized in modern methods of teaching despite the existence of a considerable number of approaches to integrate culture knowledge in the process of teaching foreign languages. At present, there is a growing need to reconsider methods and techniques of teaching a foreign language ata secondary school. At present much attention is paid to the use of foreign linguistic units revealing national identity in order to demonstrate students a great variety of national cultures.A number of domestic methologists such as V. V. Safonova [1], P. V. Sysoev [2], N. D. Galskova [3], S. G. TerMinasova [4], G. B. Elizarova [5], E. M. Vereshchagin [6], V. V. Khokhlova [7] suppose that a success in building socio-cultural competence in the process of teaching a foreign language can be achieved through the creation of a culture model of a native speaker. In this case, a proper choice of authentic language materials is of great importance. The value of such selection is measured by national and cultural semantic meaning of the units for revealing linguistic features of a foreign language. Phonetics and grammar are also studied in order to get information about the national culture of native speakers as well.

According to the research carried out by M. Byram [8], Karlfried Knapp [9], Barry Tomalin [10] cultural diversity is one of the main didactic tools to achieve the main goal - 
to improve the level of skillsand to foster the ability of students to use specific background knowledge about the target language and country in the process of cross-cultural interaction.

\section{Materials and methods of research}

The system of implementation of a cross-cultural approach at all stages of teaching a foreign language is as follows: at the first stage students are introduced to some culturespecific concept of a foreign country, mainly with the help of authentic pictures and photos. At the second stage students get acquainted with language phenomena and socio-cultural life of native speakers. The third stage comprises the information the students got about the country they study, speech and behavior patterns, developing students'integrative skills to communicate. Both formal and informal speech registers are taken into account. Thus, the ethics of discussion is being taught while discussing issues related to the culture and lifestyle of native speakers.

When determining the content of training, there is undoubtedly a debatable point about its cultural component, since the purpose of teaching foreign languages, as it was mentioned above, is not only the development of certain language skills and abilities. It's a long process of acquisition and assimilation of background information of a target language. The main goal of making the national component a part of learning process consists of studying a set of culture-specific concepts and particular speech patterns. This goal provides solutions to the following tasks:

- intensification ofthe cognitive activity of students;

- evaluation of language skills and abilities;

- students' individual development inextricably linked with the cultural studies of the target language;

-motivating students' interaction in cross-cultural communication and self-evaluation.

I. L. Bim [11] strongly emphasized the need to include elements of culture and specific information inteaching languages. In this approach we are speaking about the necessity to enrich the object of teaching with background information. Modern methods of teaching foreign languages strengthen pragmatic aspects of language learning due to status change of the language as a means of communication and mutual understanding processes of the world community. That means that achieving high-level results is of utmost impoprtance as well as searching ways to adopt a foreign culture.

According to the new FSES CE (Federal State Education Standards forCompulsory Education) [12], in addition to knowledge, speech skills, compensatory and educationalcognitive skills, the mandatory minimum content of basic educational programs includes background knowledge and skills. Their formation means the development of linguistic and cultural knowledge and increasing the number of problems to be discussed and speak on. There is no doubt that the inclusion of a national and cultural component in the content of teaching a foreign language requires adequate means for its mastering. Proverbs and antiProverbs (twisted wisdom) are considered one of the means to help teachers in solution of different tasks. It creates additional opportunities for maintaining motivation to learn a foreign language expanding intellectual horizons of students and evaluation of their language abilities. Students can understand the culture and traditions of the nation internally, as well as to study language from the linguocultural point of view. Using proverbial material, students take part in the dialogue of cultures, receive primary knowledge on grammar, syntax and phraseology, additional information about the country of the studied language. Proverbs and anti-Proverbs help to interpret speech messages in a proper way, respond correctly, express thoughts and feelings, and interact successfully. On the one hand Proverbs and anti-Proverbs don't need to be adapted; on the other hand, they 
meet the highest artistic requirements. These phrasological units are helpful in fixing culturally significant information. Therefore, huge methodological and practical significance of using these paremia in the process of teaching a foreign language shouldn't be underestimated or neglected.

However, the results of the analysis of the "Spotlight" textbooks for secondary schools reveals the lack of attention paid to the use of Proverbs in teaching English to students of different ages. They are as follows.

At the initial stage Proverbs are not included in this Learning and Teaching Support Kit, as firstly students are to be taught basic vocabulary and grammar rules aimed to be used at the next stages of learning. Mostly Proverbs are offered either as titles of coursebook units or texts, for example "Charity begins at home". Group activity tasks like "Do you agree with the proverb "We do not inherit earth from our ancestors, we borrow it from our children"? are extremely rare. Moreover, their content does not either appeal to the feelings of students or match their life experience. Very often they contain little background information. Thus, teaching effect of Proverbs and anti-Proverbs is evidently underestimated. At the same time, paremia are the most complex signs of the language [13]. Most Proverbs and anti-Proverbs have simple grammar structure and their meaning can be succinctly explained. They are served to perform a number of functions, namely:

- anticipate further information; get ready for its perception;

- explain and refine the information received;

- generalize and sum up;

- emphasize speech units;

- fill in the missing background knowledge.

Proverbs and anti-Proverbs can be used:

a) at the beginning of the lesson ( warm-up activities);

b) at the lesson to:

- introduce new words and grammar rules;

- evaluate pronunciation;

- sum up the information have been read or listened to ;

- set up subjects for discussion;

- expand background knowledge.

C) at the final stage of the lesson for providing assessment of students' activities.

Successful communication is not possible without language and speech skills. At the initial stage of evaluationof pronunciation skills Proverbs and anti-Proverbs can be used for setting the pronunciation of particular foreign sounds. This is true for the sounds not usual for a native language. The authors of the article "Place of phraseology in the study of foreign languages (on the example of Russian as a foreign language)" [14] note the importance of stable units, as well as poetic forms in the development of the so-called "hearing-motor dynamic stereotype". Here are examples of such sets (Proverb+antiProverb):

- labial sound [w]:"Where's the will, there's the way"->"Where's the will, there's a contestant";

- interdental sound $[\theta]$ : "The more the merrier"->"The more the merrier, the fewer the better fare";

- explosive sounds [p], [t], [d]:“A penny saved is a penny earned” > "A penny saved is a penny taxed";

- nasal sounds $[\mathrm{n}],[\mathrm{m}]:$ "No man can serve two masters" $\rightarrow$ "No man can serve two masters... or mistresses".

This type of work can also be used by the teacher to adjust students' organs of speech to a foreign language speaking in a very short time. 
The advantage of using Proverbs and anti-Proverbs is also justified by the fact that these units greatly contribute to the process of teaching rhythm and intonation pattrens. Students will master the ability to divide sentences into intonation groups, put word and logical stress. For example, "Curiosity killed the cat" $\rightarrow$ "Curiosity killed the cat,// but satisfaction brought it back"; "The early bird catches the worm" ->"The early bird can get a worm, //but the second mouse can get the cheese".

Proverbs and anti-Proverbs can be a good illustration of their effective usage while teaching students basic grammar and vocabulary. For example, "An apple a day keeps the doctor away" $\rightarrow$ "An onion a day keeps everyone away" (the meaning of the word"onion"). "Man cannot live on bread alone" > "Man can't live on bread alone - he has to have credit cards" (grammar: "Modal verbs"). "The more the merrier"-> "The more the merrier, the fewer the better fare" or "Two heads are better than one"-> "Two are better than one" (grammar:"Degrees of comparison of adjectives").

The following tasks aim to expand students' active vocabulary and use grammar in English speaking and writing. Here are some examples.

1) Name a Proverb / anti-Proverb by a keyword:

Money: "A fool and his money are soon parted". ->"A fool and his money are soon parted, the rest of us wait until we reach the supermarket".

2) Name as many Proverbs/anti-Proverbs as possible with a specific word, for example "book".

"A room without books is like a body without a soul".

"There is no friend as faithful as a good book".

"Bad books are worse than useless they are harmful".

"Don't judge a book by its cover".

3) Make up a statement. Put the words in the correct order:

is/mother/the/invention/mother/necessity (Proverb). "Necessity is the mother of invention".

mother/necessity/of/chances/is/the/taking (anti-Proverb). "Necessity is the mother of taking chances".

4) Fill in the gaps:

bread live cannot

"Man ___ by __ alone”(Proverb).("Man cannot live by bread alone").

can't bread has cards

"Man ___ live on ___ alone - he _ to have credit___. (anti-Proverb). ("Man can't live on bread alone - he has to have credit cards").

showers flowers

“April __ bring May __ ” (Proverb).(“April showers bring May flowers”).

showers flowers May basements

“April__ bring May ___ and ___ showers bring flooded ".( anti-Proverb) ("April showers bring May flowers and May showers bring flooded basements").

5) Make up an anti-parody based on a traditional parody:

"A ___ (noun) is an animal you __ (verb); a __ is an animal who (verb) you".

6) Name a Proverb or anti-Proverb with the numerals " 1,2,9" and findtheir Russian equivalents:

"Men are only good for one thing". -> "Men are only good for one thing - and sometimes they aren't even good for that".

"No man can serve two masters".-> "No man can serve two masters... or mistresses".

"A stitch in time saves nine".-> "A woman on time is one in nine".

7) Name and translate a Proverb/anti-Proverb with any ordinal number:

"If at first you don't succeed, try again". -> "If at first you don't succeed, go find out what the other guy did to succeed". 
The use of paremias is also advisable in teaching types of speech activity. They serve as an incentive to perform speech exercises in oral and written form, making speech sound lively and emotional. Here are some examples of using paremias for the evaluation of language skills.

1) "A man's home is his castle" -> "A man's home is his castle; let him clean it".

2) Use the Proverb "There's no place like home" $\rightarrow$ "There's no place like http://www.home.com." Compose and dramatize a dialog.

3) Come up with a situation that could confirm this message "Don't bite off more than you can chew" -> "Don't byte off more that you can view".

4) Match the picture with the following Proverb and anti-Proverb "Lightning never strikes in the same place twice" $\rightarrow$ "Lightning strikes twice" and explain their meaning.

Proverbs and anti-Proverbs are successfully used for the evaluation of students' writing skills. In this case Proverbs and anti-Proverbs act as a means of expressing thoughts and mostly contribute to practice words and grammar structures in written form. Here are some examples of Proverbs and anti-Proverbs for essay writing:"A fool and his money are soon parted" -> "A fool and his money are soon parted, the rest of us wait until we reach the supermarket"; "One hand washes the other" -> "One brain washes the other"; "A stitch in time saves nine"-> "A woman on time is one in nine".

\section{Experimental training}

Within the framework of experimental and diagnostic training, we studied the use of English paremias (Proverbs and anti-Proverbs) for the formation and improvement of foreign language and speaking skills, as well as the development of socio-cultural competence of students in grades 9 of a secondary school. The study was conducted in the 2019-2020 academic year at the experimental site of the MEI (municipal educational institution) gymnasium No. 14g. o. Orekhovo-Zuyevo, Moscow region. English lessons were given on the basis of learning kit "Spotlight" for grade 9 [15]. Due to COVID-19 pandemic the final phase of experimental and diagnostic training was held in a distant format. Experimental and diagnostic training was carried out in two groups: the first group (a group of students of 9 "A" class - 15 people) was a control group, the second group (a group of students of 9 "B" class - 15 people) was an experimental one, in which English was taught with the help of the above-mentioned learning kit, but with the use of English Proverbs and anti-Proverbs.

The experimental and diagnostic training consisted of three stages:

Stage I - ascertaning. At the first stage we conducted an entrance test to check the level of linguistic and socio-cultural students' competence of both groups. Students were asked to complete the following tasks:

1) Translate English Proverbs and give their Russian equivalents.

- Penny wise and pound foolish.

- To rob Peter to pay Paul.

- Better give a shilling than lend a lose half a crown.

- Before you make a friend eat a bushel of salt with him.

- The proof of the pudding is in the eating.

2) Make a Proverb (table 1) or an anti-Proverb (table 2).

Table 1.

\begin{tabular}{|c|c|}
\hline In for a penny & than the doctor. \\
\hline Jack of all trades & and find a farthing. \\
\hline Better pay the butcher & in for a pound. \\
\hline To waste a candle & and master of none \\
\hline
\end{tabular}


Table 2.

\begin{tabular}{|c|c|}
\hline Curiosity killed the cat & where the mortgage is. \\
\hline Good things come & the fewer the better fare. \\
\hline Home is & but satisfaction brought it back. \\
\hline The more the merrier, & to those who bait. \\
\hline
\end{tabular}

Each correct answer was rated 1 point. The maximum number of points for completing two tasks is 13 . Test scores were transferred to the traditional rating system, namely 12-13 points corresponded to the rating "excellent", 9-11 points corresponded to the rating "good", 5-8 points correspond to the rating "satisfactory". Below 5 means "poor". The results of the entrance test indicated that students of both groups had difficulties in completing task \#1 when selecting Russian equivalents of Proverbs. They failed to translate the names of English monetary units and liquid measures. This indicates a lack of background knowledge. Task \#2 caused the greatest difficulty because anti-Proverbs, representing deliberate distortion and reinterpretation of well-known Proverbs, can have a fairly unpredictable version of the language design. Charts 1-2 reflect the results of the entrance testing of students in both groups.

\section{" excellent $\square$ good $\square$ satisfactory $\square$ poor}

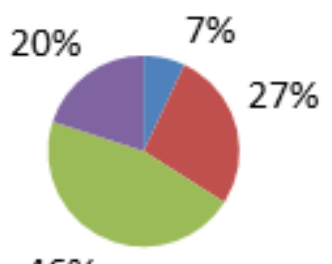

\section{$46 \%$}

Fig. 1. The results of the entrance testing of students of the control group ( 9 "A").

\section{excellent good $\quad$ satisfactory $\square$ poor}

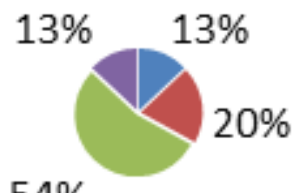

$54 \%$

Fig. 2. The results of the entrance testing of students of the experimental group ( 9 "B").

In the experimental group the average percentage of successfully completed tasks (the number of "good" and "excellent" ratings was taken into account) was $31 \%$. The indicator of the control group was $34 \%$.

Figure 3 shows the results of the entrance testing for students in both groups. 

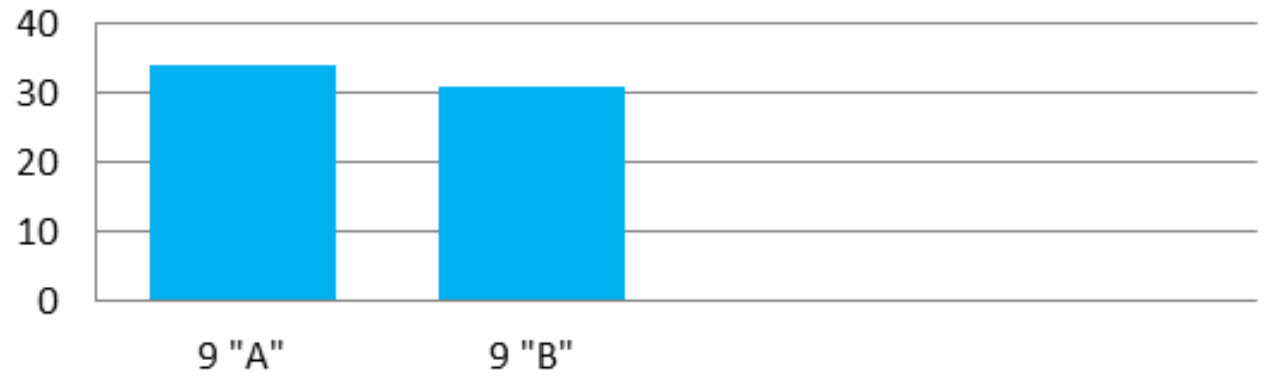

Fig. 3. The results of the entrance testing for students in both groups.

Stage II -forming. At this stage experimental and diagnostic training in the experimental group was carried out with the maximum use of English Proverbs and anti-Proverbs to improve lexical and grammatical skills and develop foreign language writing and speaking skills. Special attention was paid to the socio-cultural content of the paremiological units used. If necessary, a linguistic and cultural commentary was given. The linguo-cultural commentary reveals national peculiarities of perception of a non-linguistic fact, fills in the missing background knowledge necessary for understanding unfamiliar realities, and also reveals specifically national, cultural, everyday or other connotations [16].

Thus, to present such grammar issues as 'Conditionals' and 'Modals' the following Proverbs and anti-Proverbs were used:

- If I had given four-pence for that advice, I had bought it a groat too dear (Proverb). A linguistic and cultural commentary: "four pence" - a monetary unit equal to 4 pence).

- On Valentine's day will a good goose lay, If she be a good goose, her dame well to pay, She will lay two eggs before Valentine's day. (Proverb). A linguistic and cultural commentary: "Saint Valentine's Day" - a holiday of Catholic origin, which is named after one of the two early Christian martyrs named Valentine of interamna and Valentine of Rome.

- If Cadbury Castle and Dolbury Hill dolven were, all England might plough with a golden sheere (Proverb). A linguistic and cultural commentary: "Cadbury castle"- the English castle in the County of Somerset. According to legend, the place where the castle of king Arthur called Camelot was situated; "Dolbury hill" - the ruins of an ancient fortified settlement, where countless treasures are hidden, protected by a special spell, which people cannot overcome.

- If at first you don't succeed, skydiving is not for you (anti-Proverb).

- If you must rise early, be sure you are a bird and not a worm (anti-Proverb).

- If we can't as we would, we must do as we can (Proverb).

- Four farthings and a thimble can make a tailor's pocket jingle (Proverb). A linguistic and cultural commentary: "farthing" -1/ 4 1/4 penny.

- You may know by a penny how a shilling spends (Proverb). A linguistic and cultural commentary: "Kopeyka" - British exchange coin (1/100 pounds sterling); " Shilling" monetary unit of the Anglo-Saxon period, until 1971 was $1 / 20$ pounds sterling .

- Who would keep a cow when he may have a quart of milk for a penny? (Proverb). A linguistic and cultural commentary: "Quart" is a unit of dry or liquid volume, equal to one quarter of a gallon.

- You can't make an omelet without breaking a few eggs (Proverb).

- Misery loves company, but can't bear competition (anti-Proverb).

- Always put off 'till tomorrow what you shouldn't do at all (anti-Proverb).

Proverbs and anti-Proverbs were widely used in teaching English to students of grade 9 " B " in accordance with the logic of cognitive activity proposed by A.D. Klimentenko and 
A. A. Mirolyubov [17], starting with the stage of introducing new material the formation of orienting basis of an action (OBA) and ending with the stage of creative application of language material (carrying out communicative activitiesin oral and written forms).

Taking into account the fact that working with small literary forms effectively affects the process of teaching foreign language speaking using authentic samples of utterances, at the post-text stage of working with texts, students of the experimental group were asked to select and add a Proverb that reflects the main content of the text, and to speak in favour of the choice made, for example, when working with the text "Fears\&Phobias".

Table 3.

\begin{tabular}{|c|c|}
\hline$\ldots$ dog seldom... & Open enemies \\
\hline Beware of a silent ... and ... water & All bark and no bite \\
\hline False friends are worse than .... & Stillwatersrundeep \\
\hline
\end{tabular}

Stage III-controlling. At the final stage, students of both groups did the final testing. For a convenient way to conduct the test, Google's online service was used. Students were asked to do 3 tasks:

1. Translate English Proverbs and give their Russian equivalents.

- All work and no play makes Jack a dull boy.

-To carry coals to Newcastle.

-To waste a candle and find a farthing.

- A penny at a pinch is worth a pound.

- An ounce of prevention is worth a pound of cure

2. Choose the appropriate Proverb for these anti-Proverbs.

-There is no police like Holmes.

-A woman's place is in the House... and Senate.

-Too many clicks spoil the browse.

-A penny saved makes Jack a dull boy.

-Marry in haste, but repent in the suburbs/in Reno.

3. Comment on the situation using a Proverb or anti-Proverb.

Kim is a blogger. He has $150 \mathrm{~K}$ followers but his aim is to get more. He conducts experiments, visits dangerous places and do dangerous things. Yesterday he posted a photo putting his head into the crocodile's jaw. Now he has $160 \mathrm{~K}$ followers.

For each correct answer of the final testing, a student was given 1 point. The maximum score for the first and second tasks was 10 points. 3 points was the maximum score for the third task.

The results of the final testing are as follows (see diagrams 4-5).

шxcellent good $\square$ satisfactory

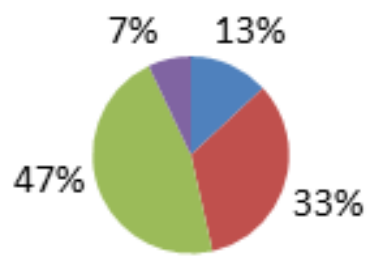

Fig. 4. The results of the final testing of students of the control group (9 "A"). 


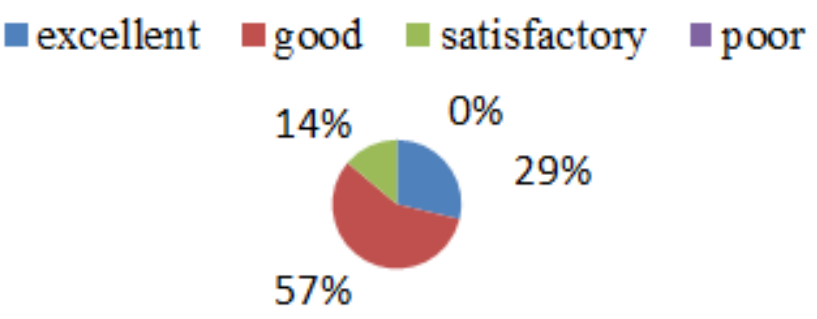

Fig. 5. The results of the final testing of students of the experimental group (9 "B").

We see that the performance of students in the experimental group improved significally. The total percentage of tasks done with "good" and "excellent" scores was $82 \%$. The result of the group controlled was $46 \%$.

Figure 6 shows the combined results of the entrance and final testing of students in both groups.

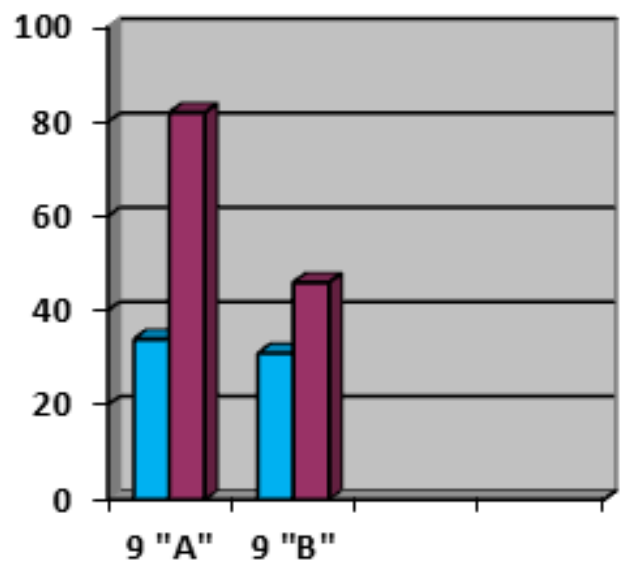

口entrance testing

口final testing

Fig. 6.

Thus, the conducted experimental and diagnostic training aimed at improving the level of learning and the development of socio-cultural competence of students through the use of paremiological units in the process of teaching English, gave a positive result and proved its effectiveness.

\section{Discussion}

According to the research, the use of proverbial material is methodologically justified at all stages of foreign language teaching. Moreover, paremiological units, being a cultural component of any nation and included in the vocabulary of any language, allow you to delve not only into foreign culture, but also to study the linguistic features of a foreign language. The development of social and cultural competence of students contributes to the saturation of Proverbs and anti-Proverbs background vocabulary, reflecting a large layer of ideas about the culture, traditions and customs of the country of a target language. 


\section{Conclusion}

Foreign language teaching cannot be complete and comprehensive without reference to the culture of native speakers, therefore the mandatory minimum content of contemporary educational programs included background knowledge and speech skills that is information on the country of the target language, spiritual values and cultural traditions, peculiarities of national mentality and identity. In other words, social and cultural characteristics become not additional, but the main characteristics of the process of teaching.

The use of Proverbs and anti-Proverbs in the process of teaching a foreign language to secondary school students is necessary for the evaluation language and speech skills, the development of social and cultural competence, closely related to the process of teaching the language itself

\section{References}

1. SafonovaV.V. Sociokul'turnyj podhod k obucheniju inostrannym jazykam. - M.: Vysshaja shkola, Amskort Internjeshnl, 1991. - 305 s.

2. Sysoev P.V. Kul'turnoe samoopredelenie obuchajushhihsja v uslovijah jazykovogo polikul'turnogo obrazovanija / P.V. Sysoev // IJaSh. 2004. № 4. -S. 14-20.

3. Gal'skova N.D. Sovremennaja metodika obuchenija inostrannym jazykam: posobie dlja uchitelja / N.D. Gal'skova. M.: ARTI GLOSSA, 2000. - 165 s.

4. Ter-MinasovaS.G. Jazyk i mezhkul'turnaja kommunikacija / S.G. Ter-Minasova. M.: Slovo, 2000. - $624 \mathrm{~s}$.

5. Elizarova G.V. Kul'tura i obuchenie inostrannym jazykam / G.V. Elizarova. - SPb.: KARO, 2005. - 352s.

6. VereshhaginE.M. Jazyk i kul'tura: lingvostranovedenie v prepodavanii russkogo jazyka kak inostrannogo / E.M.Vereshhagin, V.G. Kostomarov. 4-e izd. -M. :Russkijjazyk, 1990. - $246 \mathrm{~s}$.

7. Hohlova V.V. Osobennostivosprijatijakul'turystranyizuchaemogojazyka/V.V. Hohlova // Inostrannyejazyki v shkole. 2004. - № 3. - S. 76-80.

8. Byram M. Teaching-and-learning language-and-culture / M. Byram, C. Morgan. Philadelphia : Multilingual Matters LTD, 1994. - 219 p.

9. Knapp Karlfried. Intercultural Communication in EESE // http://www.cs.uu.nl/docs/vakken/bci/programma/intercult.html Retrieved January 3, 2003.

10. Barry Tomalin, Susan Stempleski. Cultural Awareness. OxfordUniversityPress, 1994.$168 \mathrm{p}$.

11. Bim I.L. Lichnostno-orientirovannyj podhod - osnovnaja strategija obnovlenija shkoly. Inostrannye jazyki v shkole. 2002. №2. - S.11-15.

12. FGOS - Federal'nye gosudarstvennye obrazovatel'nye standarty [Jelektronnyj resurs]. URL: https://fgos.ru/ (data obrashhenija: 31.07.2020).

13. AbakumovaO.B., Korostenski J. Reference, evaluation and codes of culture in Russian and Czech proverbs of truth and lie.XLinguae, Volume 13 Issue 4,2020. pp. 133-139.

14. Katsyuba L.B., Ismailova K.E., Bondareva O.V. Place of phraseology in the study of foreign languages (on the example of Russian as a foreign language). XLinguae, Volume 13 Issue 2, 2020. pp.92-101. 
15. Anglijskij v fokuse. Spotlight. 9 klass. Vaulina Ju.E.- M.: Prosveshhenie, 2019. -216 s.

16. Nacional'naja kul'tura cherez prizmu poslovic. [Jelektronnyj resurs].URL:https://studbooks.net/2096915/literatura/natsionalnaya_kultura_prizmu_p oslovits(data obrashhenija: 11.07.2020).

17. Klimentenko A.D., Miroljubov A.A. Voprosy metodov obuchenija inostrannym jazykam. Sovetskaja pedagogika, №7, 1978. - S.34-40. 